\title{
KOULUTUS JA KOLLEGAT PITÄVÄT KIRJASTOLAISET KARTALLA
}

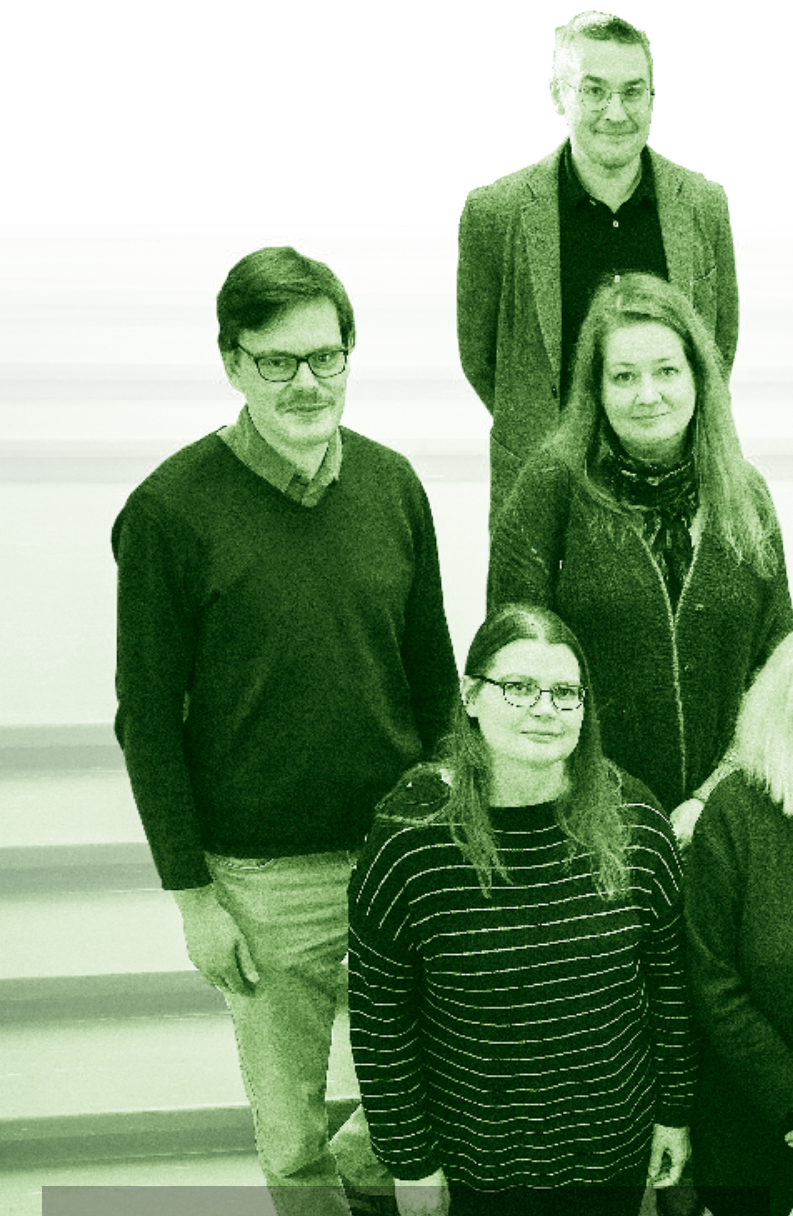

STKS tarjoaa mahdollisuuden verkostoitumiseen, ammatillisen osaamisen kasvattamiseen ja vaikuttamiseen. Kirjasto- ja tietopalvelualalla pitäisi puhua tulevaisuudesta - muutoksesta, yhteisestä suunnasta ja uusista teknologioista. 90-vuotiasta seuraa tarvitaan jatkossakin kouluttamiseen, yhdessä tekemiseen ja alan kehityksen seurantaan. Tässä yhteenvetona STKS:n uuden hallituksen vastauksia Signumin tiedusteluun. 
Suomen Tieteellinen Kirjastoseuran (sTKs) uusi hallitus vuosille 2020-202 I aloitti toimintansa, ja kysyimme heiltä:

I. Mikä sinua kiinnostaa STKs:n toiminnassa? Mitä sTKS antaa sinulle?

2. Mistä kirjastoalalla pitäisi puhua juuri nyt?

3. STKS täytti 90 vuotta - mihin sitä tarvitaan vielä tänään ja huomennakin?

\section{Pälvi Kaiponen}

Helsingin yliopiston kirjasto, sTKs:n hallituksen puheenjohtaja

I. "Seurassa toimiminen antaa erinomaisen mahdollisuuden verkostoitua eri kirjastosektoreiden asiantuntijoihin. Erityisen tärkeänä pidän sitä, että seura toiminnallaan tukee jäsenistöä kirjastoalan jatkuvasti kehittyvässä ja muuttuvassa toimintaympäristössä ja siten osaltaan mahdollistaa jäsenten ammatillisen osaamisen kasvun. Myös seuran tehtävä, kirjastojen osaamisen ja roolin esiintuominen välttämättömänä osana koulutusta ja tutkimusta, innostaa."

2. "Uusista teknologioista ja niiden hyödyntämisestä, esimerkiksi tekoälystä ja sen sovellusalueista kirjastoissa. Alamme ammattilaisilla on ollut aina valmius tarttua kehittyvään teknologiaan ja siten tuoda asiakkailleen edistyneitä palveluita tutkimuksen, opetuksen ja opiskelun tueksi. Seura onkin perustanut uuden työryhmän seuraamaan tätä kehitystä ja kouluttamaan jäsenistöä näihin haasteisiin.”
3. "Tieteelliset kirjastot tarvitsevat jatkossakin laadukasta koulutusta henkilöstölleen. Tarvitaan toimiva asiantuntijoiden verkosto, joka seuraa alamme kansainvälistä kehitystä, laatii ajankohtaisia koulutussisältöjä ja levittää tietoa keskeisistä kehityssuunnista laadukkaan viestinnän ja erityisesti oman ammattijulkaisumme Signumin kautta. Jäsenistömme on tärkein voimavaramme. Seuramme on aatteellinen järjestö, jonka sitoutuneet jäsenet mahdollistavat tuellaan tieteellisten kirjastojen näkyvyyden ja äänen tieteellisen toiminnan kentässä.”

\section{Katja Hilska-Keinänen \\ Suomen ympäristökeskus}

I. "Olen seuraillut sTKs:n toimintaa vuodesta 2000 alkaen, ja palattuani nyt tieteellisten kirjastojen pariin Suomen ympäristökeskuksen tietopalveluun halusin liittyä toimintaan tiiviimmin. Minulle verkostot merkitsevät hyviä yhteistyösuhteita, alan kehittämistä yhdessä ja nopeaa tiedonsaantia. Näen, että voin sTKs:ssä sekä antaa että saada näkemyksiä ja osallistua alamme tulevaisuuden vahvistamiseen.”

2. "Meidän pitäisi puhua tulevaisuudestamme siten, että katsomme kirjastojen ja tietopalvelujen toimintaa osana asiakaskuntamme ja emo-organisaatioidemme toimintakenttää. Tutkimuksen tekeminen, tieteellinen viestintä ja niihin kohdistuvat odotukset ovat murroksessa ja siten myös meidän toimin- 
tamme tieteellisen tiedon tuottamisen tukena. On äärimmäisen tärkeää pystyä keskustelemaan idearikkaasti, ratkaisukeskeisesti ja luottamuksellisesti alaamme kohdistuvista muutoksista ja uusista toiminta-alueista."

3. "Arvostan suuresti yhdistyksen pitkää historiaa, samoin kuin alamme neljätuhatvuotisia juuria. Tällaisesta pitkäikäisestä yhdistyksestä käsin on hyvä tarkastella myös tulevaisuutta: miltä tieteellisten kirjastojen toimintakenttä näyttää 20, 50 tai sadan vuoden päästä? Kiteytetysti sanoisin, että STKs:ää tarvitaan yhteisen tulkinnan muodostamiseen ja tulevaisuutemme tekemiseen.”

\section{Anne Holappa}

Tekijänoikeuden tietokeskus

I. "Minua kiinnostaa eniten verkostoituminen saman alan kollegojen kesken. Teen töitä yksin, tarvitsen ammatillisia vertaisryhmiä. Arvostan myös koulutustoimintaa, jota seura järjestää.”

2. "Murroksesta, mikä kirjastoalalla on juuri nyt meneillään. Kirjastoalahan on aina muutoksessa. Mutta nykyään muutos tai murros näyttäytyy minulle siten, että en edes ymmärrä vaatimuksia, joita alan työpaikkoihin vaaditaan. Mihin tässä oikein ollaan menossa?"

3. "Seuraa tarvitaan vahvana toimijana kirjastokentällä, tieteellisten kirjastojen puolestapuhujana."

\section{Tuija Korhonen}

Helsingin yliopiston kirjasto

I. "sтKS on kirjastoalan näköalapaikka, ja toiminnassa mukana olemalla pysyy ajan tasalla siitä, mitä kirjastoalalla tapahtuu. Parasta ovat eri kirjastojen mukavat kollegat, joiden kanssa voi verkostoitua."

2. "Kirjastotyö on muuttunut paljon ja muuttuu koko ajan, mutta kirjastolaisten imago yleisessä tietoisuudessa ei ole muuttunut. Miten pysyä asiantuntijana muutoksessa mukana?”

3. ”sTKs:n rooli täydennyskouluttajana on ollut merkittävä, ja koska ala kehittyy nopeasti, sTKs tulee myös jatkossa olemaan merkittävä täydennyskoulutuksen tarjoaja. STKs:n on oltava valmis reagoimaan alan muutoksiin nopeastikin."

\section{Virpi Kultanen \\ Kela (tutkimusyksikkö)}

I. "Toiminnassa kiinnostaa oman panoksen antaminen kirjasto- ja tietopalvelualan kehittämiseen ja vaikuttamisen mahdollisuudet. STKs antaa areenan pysyä kärryillä siitä, mitä alallamme tapahtuu, ja erinomaisen mahdollisuuden ylläpitää ja laajentaa omia verkostoja sekä laajentaa näkemystä ajankohtaisista aiheista. Myös koulutusten järjestäminen ja niihin osallistuminen on itselleni sTKs:n toiminnassa tärkeää ja kiinnostavaa.” 
2. "Koulutuksen tulevaisuudesta, osaamisen profiloimisesta ja osaamisen brändäämisestä. Kirjasto- ja tietopalvelualan ammattilaiset ovat mestareita ottamaan haltuun uusia teknologioita, tehtäviä ja aihealueita mutta edelleen mielestäni alan osaamista ja osaajia arvostetaan ja nostetaan esille ihan liian vähän.”

3. "stks on yhtä kuin sen jäsenet. Perinteisten yliopistokirjastojen lisäksi STKS edustaa myös ammattikorkeakouluja ja erikoiskirjastoja ja sitä tarvitaan kaikille näille sektoreille tärkeiden aihepiirien esiinnostajana ja äänitorvena. Täydennyskoulutuksen järjestäjänä STKS:n rooli on keskeinen ja näen sen merkityksen vahvistuvan tulevaisuudessa. STKs on tärkeä myös verkostoitumisen näkökulmasta.”

\section{Johanna Lahikainen \\ Helsingin yliopiston kirjasto}

I. ”sтKs:n työryhmissä ja seminaareissa oppii, virkistyy ja tapaa innostavia kollegoita oman arjen ulkopuolelta."

2. "Pian avautuvasta mahdollisuudesta hakea sTKs:n keväällä käynnistyvään Uudet teknologiat -työryhmään.”

3. "Seurassa, yhdessä, voimme vaikuttaa enemmän kuin yksin. Professori Laura Kolben mukaan 'kirjastojen ja kirjastoammattilaisuuden kuuluu mennä eteenpäin, elää ajan ja teknologian mukana. Osaamiseen tu- lee uusia kerrostumia. On kuitenkin tärkeää säilyttää vanhaakin osaamista eikä pyyhkiä sitä pois uuden tieltä. Meillä usein nähdään asiat turhan mustavalkoisesti: joko tai, ei sekä että - joka olisi parempi tapa'. (Signum I/20I 8) Vuonna 20I 8 julkaistun eduskunnan tulevaisuusvaliokunnan raportin mukaan tulevaisuudessa tarvitaan esimerkiksi kohinanpoistajia, jotka vähentävät informaatiovirran turhaa hälyä, kiteyttävät olennaisen, sekä tekoälynkatsastajia, jotka katsovat, että tekoäly tekee järkeviä ratkaisuja ihmisiin liittyvissä päätöksissä. Tarvitaan myös manipulointietsiviä, jotka selvittävät uutisten taustoja ja tekijöitä: mihin uutisiin voi uskoa, mihin ei? Kirjasto- ja informaatioalan ammattilaiset ovat oivallisia tällaisissa töissä. (Ks. Signum 2/201 8)"

\section{Sinikka Luokkanen}

Hämeen ammattikorkeakoulu, sTKs:n hallituksen varapuheenjohtaja

I. "Verkostoituminen, yhdessä oppiminen, yhdessä tekeminen, yhdessä kehittäminen sekä yhdessä mielenkiintoiseen ja haastavaan tulevaisuuteen valmistautuminen. STKs:n piiristä löydän samassa kontekstissa toimivat kollegat ja yhteisöllisyyden voiman.”

2. ”Liikkeellä olemisesta. Luonto ja maailma ympärillä muuttuvat koko ajan. Jos emme halua sammaloitua, meidän on oltava liikkeellä. Meidän pitäisi puhua siitä, mihin haluamme 
alana olla menossa. Jos emme alana määritä liikkeen suuntaa, ala hajoaa kuin kirppulauma kaikkiin ilmansuuntiin ja menettää merkityksen ja oman identiteetin."

3. "Siihen samaan kuin tähänkin asti: yhdessä tekemiseen. Meillä on pienet tieteelliset kirjastot, joten missään ei ole resursseja tehdä kaikkea yksin. Ja sitä paitsi, minusta ainakin, yhdessä tekeminen on hauskempaa."

\section{Petri Tonteri \\ Tampereen yliopiston kirjasto}

I. "Koen sTKs:n tuiki tärkeäksi toimijaksi kirjastokentällä, se on: keskustelunherättäjä, kannanottaja, koulutusten järjestäjä, kirjastoalan verkostoissa toimiva organisaatio.”

2. "Monta on tärkeää aihetta puhuttavaksi, mutta tieteellisten kirjastojen puolelta haluan nostaa ainakin nämä: Avoin tiede ja miten kirjasto voi avointa tiedettä edistää? Mikä kirjastojen rooli on muuttuvassa tiedemaailmassa? Mitkä ovat kirjastoalan osaamistarpeet ja mihin suuntaan ne ovat menossa? Kirjastoverkoston tila: mikä tilanne on alan opetusta antavissa kouluissa, miten kirjastojen välinen yhteistyö jatkuu nyt esimerkiksi kirjastojärjestelmämuutosten jälkeen?”

3. ”Toki tänään ja huomennakin on tarvetta sekä alan sisäiselle keskustelulle että vuoropuhelulle muun yh- teiskunnan kanssa. Alaan kohdistuvien muutostrendien osalta on oltava hereillä. Koulutustarve ei poistu niin kauan kuin tällä kamaralla kirjastolaisia vaeltaa. Näissä kaikissa stKs:lla on panoksensa annettavanaan."

\section{Aija Vahtola \\ Kansalliskirjasto}

I. "Verkostoitumisen lisäksi kirjastoalan osaaminen on kasvanut, ja uusia asioita ja ilmiöitä pääsee käsittelemään monipuolisesti eri sektoreilta tulevien kollegoiden kanssa."

2. "Kirjastojen merkitys luovuuden mahdollistajana sekä tiedon ja tutkimuksen perustana korostuu yhteiskunnassamme entisestään. Digitaalisuuden tuomien mahdollisuuksien ja avoimuuden varmistaminen kirjaston tuottamissa palveluissa ovat keskiössä, samoin tutkitun tiedon saatavuuden varmistaminen.”

3. "Osaamisen kehittämiseen, kirjastojen tunnettuuden lisäämiseen ja verkostoitumiseen.”

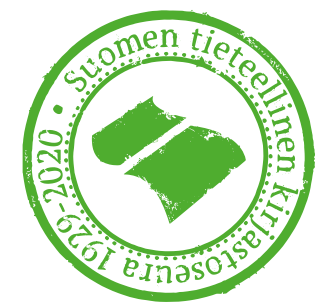

